\title{
The ILO's Shifts in Child Labour Policy: Regulation and Abolition
}

\author{
Edward van Daalen and Karl Hanson
}

\begin{abstract}
After wwII the International Labour Organization (ILO) slowly but surely developed a 'two plank' approach to child labour, aimed at harmonising the need to protect children who do work, with the long-term goal of abolishing all forms of child labour. During the 1990s the 'two plank' approach, which included the regulation and humanisation of children's work, gradually evolved into a more singular approach aimed only at the full eradication of all child labour, starting with the 'worst forms'. Based on an analysis of the relevant legal and policy documents produced by the ILO and other international Organizations, completed with in-depth interviews with key informants, we examine the internal and external developments that made the 'abolitionist' approach now the only perspective that shapes the ILo's child labour policies. We conclude that, after a century of ILO child labour policy, the intermediate objective of improving children's working conditions is now just as relevant as it was before the turn away from the 'two plank' approach. For the ILo to shift its position at this time, it needs to reach out to the research community, international development actors as well as local governments and social movements to develop locally relevant, evidence-based policies for dealing with the diversity of children's work in the world's fast changing formal and informal economies.
\end{abstract}

\section{Introduction}

The abolition of child labour has been one of the principle objectives of the International Labour Organization (ILO) ever since its inception in 1919. However, when analysing legal and policy documents issued by the ILO over the last 100 years, a more nuanced picture emerges that shows how the ILO had durably adopted a dual approach to child labour. This approach included the abolition of child labour in the long run combined with transitional measures aimed at improving the working conditions of children. This approach was, for instance, made explicit in the ILO's 1979 Resolution Concerning the

(C) EDWARD VAN DAALEN AND KARL HANSON, 2019 | DOI:10.1163/9789004399013_008

This is an open access chapter distributed under the terms of the prevailing CC-BY-NC license at the time of publication. 
International Year of the Child and the Progressive Elimination of Child Labour and Transitional Measures, which calls upon member states to 'take all necessary social and legislative action for the progressive elimination of child labour and, during the transitional period until the elimination of child labour, to regulate and humanise it' (ILO, 1979c). This dual approach to child labour, which would later be coined 'the two planks of ILO policy', occupied a central place on the ILO's agenda, in particular between 1979 and 1999, before it gradually disappeared to make way for a more singular approach aiming at the eradication of all forms of child labour, starting with the worst.

On the eve of the ILO's centenary we seek to rescue from oblivion the Organization's commitment to combining the progressive elimination of child labour with its regulation and humanisation, which seems to have disappeared from the Organization's own collective memory. By looking into how and why this two-plank policy came to be, and how and why it seems to have disappeared and been forgotten, we try to make sense of the ILO's shift from the progressive elimination of child labour and the protection of children at work to its current priority of the 'sustained eradication' of the worst forms of child labour. Section 2 looks at the period between 1919 and 1946, during which the foundation was laid for a flexible and pragmatic approach to child labour. In Section 3, we then discuss the period between 1946 and 1992, during which the two-plank approach of 'protecting and regulating while eliminating' was developed and crystallised. How and why the discourse gradually changed to 'the worst forms of child labour' is addressed in Section 4. In the last section, we look at some of the tensions that were revealed by the study of shifts in ILO child labour policies.

The data that informs this chapter was gathered through document analysis and multiple in-depth interviews. Over 50 ILO documents-including declarations, resolutions, reports and other publications relevant to the scope of this chapter - were identified and studied. Guided by these findings, nine in-depth interviews were conducted with key informants selected on the basis of their position in the ILO, or in other Organizations closely involved, at crucial times during the process described below. The informants were promised anonymity and will be addressed by their professional function only.

\section{The Abolition of Child Labour as a Long-Term Goal (1919-46)}

$\mathbf{2 . 1}$ The 1919 Constitution and the Abolition of Child Labour

The Constitution of the ILO was first published as Part XIII of the 1919 Versailles Peace Treaty, which made the ILO an independent organization within the framework of the League of Nations. Annexed to Part XIII was Article 427/ 
Article $41,{ }^{1}$ which consisted of nine 'labour clauses' that were those 'methods and principles for regulating labour conditions' considered to be 'of special and urgent importance' for the future of the Organization (ILO, 1919). Among them was 'the abolition of child labour and the imposition of such limitations on the labour of young persons as shall permit the continuation of their education and assure their proper physical development' (ILO, 1919). Unfortunately, the legislative history of the ILO Constitution provides no information regarding what exactly was meant by the abolition of child labour. All that is clear is that in the two earlier draft versions of the article there was no mention of a general 'abolition of child labour' clause, but instead a more specific reference to a minimum age for admission to work in industry and commerce, set at 14 years. Dahlén (2007) argues that governments and the labour movement had pushed for the regulation of children's and women's work-as they were seen as a threat to WWI soldiers re-entering the labour market-but that a constitutional commitment to a specific minimum age was thought of as too controversial for non-industrialised nations. Where the text of the Constitution was hence limited to referring to the abolition of child labour in general terms, the ILO immediately, as of 1919 onwards, began to set standards on minimum ages by means of adopting sector-specific conventions aimed at regulating the 'non-beneficial' forms of child labour. These sector-specific conventions adopted a pragmatic approach to some forms of child labour that were not considered intrinsically problematic. In undertakings where only members of the same family were employed as well as when its purpose was to educate or train young people, child employment was even considered to be beneficial (Hanson and Vandaele, 2003). At the onset of wwII, only very few countries had ratified these sectorial minimum age conventions.

\subsection{A New World Organization and a New, Flexible Approach}

By adopting the Declaration of the Aims and Purposes of the International Labour Organization (better known as the Declaration of Philadelphia) in 1944, the ILO started shaping its future role in the 'new world Organization' governed by the UN-of which it would become the first Specialized Agency in 1946. This meant it had to revise its 'old world' Constitution (ILO, 1946, 10). Consequently, a special delegation was tasked with 'remodelling' and 'reequipping' the ILO and its Constitution. The most significant amendment was the incorporation of the Declaration of Philadelphia, which thus stated the new aims and purposes of the ILO. A member of the Delegation explained that it 'would seem unnecessary to retain in the Constitution Article 41, which sets

1 Article 427 became Article 41 when, in 1934, the ILO stepped out of the framework of the League of Nations and its constitution became independent from the Versailles Treaty. 
forth certain methods and principles for regulating labour conditions which were regarded in 1919 as being of special and urgent importance' (ILO, 1946, 20). One of the parts of Article 41 that was omitted was 'the abolition of child labour', which was thought of as having lost its 'special and urgent importance' in the new world Organization of labour. This seemingly had much to do with the so-called general considerations to which the Delegation attached 'the highest importance' (ILO, 1946, 15). First and foremost, the Delegation wanted a flexible constitution because 'rigidity is likely to result in frustration rather than progress' and 'nothing in the existing practice and tradition of the Organization can be regarded as sacrosanct whenever new needs create new requirements' (ILO, 1946, 15).

One year after the Declaration of Philadelphia but one year before the newly amended Constitution was adopted, the Resolution Concerning the Protection of Children and Young Workers was submitted to the 1945 Conference in Paris by the Committee on the Protection of Children and Young Workers. In a way, the Resolution rescued the ILO's constitutional commitment to the abolition of child labour, at least on paper, by explicitly referring to Article 41 of the 1919 Constitution just before it would be omitted. However, in its report about the Resolution the Committee recognises that the objective to abolish child labour 'may fail in its effect if at the same time no solution is found for other wider social problems - poverty, family disorganisation, inadequate facilities for education, etc. - which lead as an inevitable consequence to the employment of children at an early age' (ILO, 1945a, 3). The Committee argued that in many countries it is inevitable for young children to work due to the specific social and economic circumstances, and that until those circumstances change, the mere 'prohibition of employment may do more harm than good' (ILO, 1945a, 3). This principle is reflected in the policy set by the Resolution: 'exemptions permitting the employment of children of school age outside school hours should be eliminated as soon as possible and pending such elimination should be strictly limited [...]' (ILO, 1945b). With hindsight, the 1945 ILO Resolution Concerning the Protection of Children and Young Workers can be seen as a harbinger of the ILO's two-plank policy on child labour, the advent of which we will discuss in detail in the following section.

The Two Planks of ILo Policy (1946-92)

3.1

The Post-War Years and Convention No. 138

While the decades following WwII brought economic prosperity to most Western countries, tensions between them and other ILO member states rose, especially concerning the implications of the Organization's aim to achieve 'social 
justice' (Maupain, 2013). Besides the Cold War divide, the majority of member states were now 'independent' Third World countries with stagnating or declining economies. Although the situation in many Third World countries led to a new surge in child labour, the ILO kept relying on its 1945 policy of 'promoting' the sector-specific minimum age conventions and urging governments to take protective measures pending abolition. ${ }^{2}$

It was only when, in the early 1970s, the beginning of the end of the 'golden age' led to concerns about mass unemployment that discussions about a new and more comprehensive legal instrument on child labour were started (Dahlén, 2007). With the adoption of the 1973 Convention No. 138 on the minimum age for admission to employment, the ILo finally gave a blanket legal definition of the term 'child labour.' ${ }^{3}$ In short, for the ILO 'child labour' in 'developing countries' constitutes: all work carried out by children under 12, work by children between 12 and 14 that is not 'light' work, and 'jeopardising' or 'hazardous' work carried out by children younger than $16 .{ }^{4}$ Besides Convention 138 's general aim of achieving the total abolition of what was now legally defined as 'child labour', the supplementary Recommendation No. 146 on minimum ages provides further guidelines for implementation and stresses the importance of ensuring 'that the conditions in which children and young persons under the age of 18 years are employed or work reach and are maintained at a satisfactory standard' (para. 12(1)). This recommendation addresses the importance of improving the working conditions not only of children and young people who are legally permitted to work, but also of all persons under the age of 18 years who are employed or work, independently of the minimum ages. These conditions involve fair remuneration; the limitation of daily and weekly working hours so as to allow enough time for education and training, for rest and for leisure activities; the granting of a 12 hours' night rest and of weekly rest days; annual paid holidays; social security coverage, including employment injury, medical care and sickness benefit schemes; and satisfactory standards of safety and health (para. 13(1)). Much like all the previous minimum age conventions that it was supposed to replace, Convention No. 138 received only very few ratifications in the first years after its adoption. ${ }^{5}$

2 The minimum age conventions that were adopted during that period were specifically aimed at night work (No. 79 and No. 9o), fishermen (No. 112) and work underground (No. 123).

3 Convention concerning Minimum Age for Admission to Employment, https://www.ilo.org/ dyn/normlex/en/f?p=NORMLEXPUB:12100:0::NO::P12100_ILO_CODE:C138 (accessed on 1 June 2018).

4 Different minimum ages apply for 'developed' countries. See Articles 2, 3 and 7 of Convention No. 138 .

5 Up until 1979 only 22 countries had ratified the Convention. 


\subsection{The International Year of the Child}

In 1976 the UN's General Assembly adopted a resolution on the International Year of the Child (IYC), which would be held in 1979-20 years after the adoption of the Declaration of the Rights of the Child. The purpose of the IYC was to provide a framework for advocacy, 'to make governments and people hold up a mirror to their consciences and examine their failures on behalf of their children' (Black, 1986, 356). The ILO took up a mirror as well. After it was involved in the preparatory work of the IYC advisory group, it made the following statement: 'It is a well-known fact that, despite the efforts made by the ILO and member States to abolish child labour, there exists a substantial number of children, particularly in developing areas of the world, who are at work, often in exploitative conditions. No doubt, they belong to the most vulnerable category for whom the IYC intends to offer intensive assistance. The immediate question would be how the ILO should confront this reality of working children and reconcile it with the long-term objective of eliminating child labour; how to harmonise the need to protect these working children with the existing ILO activities in order to relate policy action to IYC' (ILO, 1978a, 1).

The intention of understanding the complex situations in the developing world and adapting policy accordingly, instead of the other way around, was in line with a new way of 'development thinking' that had taken hold of other UN Organizations as well. The United Nations Educational, Scientific and Cultural Organization (UNESCO) especially had taken on the task of spreading information about the process of world development, with a 'rejection of crude and simplistic messages' and 'a desire to learn more about the complexities of trying to transform underprivileged societies' (Black, 1986, 362). The ILO's learnings resulted in combining the long-term objective of eliminating child labour with 'transitional policy measures' to promote working children's welfare, particularly in developing countries (ILO, 1978b, 1). The ILO was then quick to point out that this 'dual concern' had motivated the Organization ever since the first minimum age convention, in 1919 (ILO, 1979a, 4). This policy was made public and explicit during the actual IYC in 1979, in the Director General's Declaration Concerning the International Year of the Child. It urges governments to strengthen their action programmes for children and stresses that one of the principles that should guide these attempts is that 'pending the elimination of child labour, it must be regulated and humanised' (ILO, 1979b). A few months later, the ILO adopted the Resolution Concerning the International Year of the Child and the Progressive Elimination of Child Labour and Transitional Measures, which reaffirmed the Organization's commitment to, as the title suggests, progressively eliminating child labour and regulating and humanising it by means of transitional measures (ILO, 1979c). After the 1945 
Resolution, this was only the second general resolution on child labour that the ILO had adopted.

\subsection{A Successful Policy Framework}

In the years following the IYC, the thus formulated ILO child labour policy framework was reaffirmed, most importantly in the 1983 Report of the DirectorGeneral. This report states that 'the elimination of child labour as an objective coupled with a commitment to action, pending its attainment, to improve the conditions of working children are the two planks of ILO policy' (ILO, 1983, 5 ; emphasis added). It also made it clear that although the goal of improving the conditions of children that do work was listed as a 'short-term goal', it was thought of as a long-lasting one: 'pending the improvement of economic conditions to the point where it will no longer be necessary or profitable for children to work, efforts must be made to complement long-term employment and development policies with progressive measures aimed at regulating and humanising child work' (ILO, 1983, 19). The report also provides clarity regarding what was to be the most important goal of these progressive measuresnamely, 'to deal with the worst forms of child labour wherever they exist, and to provide minimum levels of protection where such labour is unavoidable' (ILO, 1983, 19). It furthermore stresses that child labour legislation, even if in line with the ILO Conventions, should 'never be implemented in isolation from the socioeconomic setting' as it may lead to 'greater clandestine work and more exploitative work situations' (ILO, 1983, 19).

Two years later, in a report entitled Towards a Global Programme of Action on Child Labour, the ILO went one step further in the promotion of its progressive and pragmatic approach. According to the Organization, 'a reduction in the incidence of child labour can provide for improved terms of employment for children' and countries should thus 'set realistic quantitative and qualitative targets such that there will be a gradual reduction in the incidence of child labour while they provide for the protection of those who are and will continue to be at work until such time that the abolition objective is attained' (ILO, 1985, 5). The 1985 report also re-prioritises the two planks of ILO policy: countries must aim to first improve the conditions of working children, and secondly gradually abolish child labour (ILO, 1985).

It is important to note that at the same time the International Confederation of Free Trade Unions (ICFTU) - the most influential Organization on the workers' side of the ILO's tripartite system - was fully supporting the twoplank policy. In 1979 the ICFTU itself adopted two resolutions concerning the IYC and in its 1986 report on 'how to combat child labour' it urges trade unions 'to complement long-term employment and development policies with 
progressive measures aimed at regulating and humanising child work' (ICFTU, 1986, 26). According to the ICFTU, it was 'the only realistic approach' and 'longterm measures ought not to rule out short-term action' (ILO, 1989, 53).

What the two-plank policy had accomplished in practice, during the first ten years since the IYC, was laid out in a 1989 special report of the Director General. The ILo had witnessed a 'growing reorientation of public policy and programmes as policy-makers and practitioners search for pragmatic and effective new approaches to the concentration of child labour' (ILO, 1989, 25). This had led to a 'remarkable surge' in creative projects, conducted by governments and NGOs alike, to 'prevent the abuse of child labour and to protect and assist those children who do work' (ILO, 1989, 30). For the ILO, these creative projects represented 'a reason for optimism in the long-term struggle against child labour’ (ILO, 1989, 25).

Immediate Action for the Elimination of the Worst Forms of Child Labour (1992-present)

\subsection{The IPEC in Practice}

In 1992 the ILO launched the International Programme on the Elimination of Child Labour (IPEC), which, at first, was intended as the technical cooperation arm of the ILO's Interdepartmental Project concerning child labour. It is important to note that the IPEC was not born out of an internal drive to provide technical co-operation to members regarding child labour. Soon after the Director General had announced the launch of the Interdepartmental Project, the government of Germany announced that it would make a fiveyear-long annual donation of around USD 7 million for an ILO programme on child labour. With and especially for this donation, the IPEC was created. The founding document of the IPEC states that the long-term objective of the programme is the effective abolition of child labour. For the two immediate objectives the document refers to the 1979 Resolution concerning the IYC. The first is to help countries design and implement policies, programmes and projects for the elimination of child labour and the protection of working children. The second is to raise global awareness concerning child labour and the consequences thereof.

Before the IPEC started, the ILO had already facilitated a project aimed at improving the conditions of children working at a garbage dump in Manila, Philippines, the so-called Smoky Mountain. It started in 1987 and it was the ILO's first ever technical cooperation project on child labour. Yet, to one of the ILO experts who was involved in the project, it was more a tool of 
advocacy. The media coverage of young children working on a smoking mountain of garbage combined with previously released global statistics on child labour helped the ILO to draw attention to the issue (interview with a former ILO staff member). With the IPEC in place the ILO was now ready to provide more structural technical assistance inside member states. The IPEC's first Implementation Report showed that the implementation of the programme was in line with the two-plank policy. Projects in India and Thailand were mainly focused on improving the conditions of working children (ILO, 1993a). In Brazil, working children were trained in order to defend their rights as workers and to guide them to 'get organized and encourage their involvement in trade unions' (ILO, 1993a, 11).

In a 1993 report on the implications of the ILO's child labour policy for the cooperation activities in the field, the ILO states that while the primary aim of the IPEC is to 'promote and support action in ILO member States which contributes to the effective abolition of child labour', as a transitional measure, the 'protection of working children, especially in terms of improving their conditions of work, can constitute another objective of technical cooperation' (ILO, 1993b, 2). However, now that the ILO itself would be responsible, to some extent, for the implementation of the two planks, the Organization became more conscious of its wording, and pointed at a potential conflict between the objectives to abolish and to regulate child labour by stating that it is of the greatest importance, in technical cooperation activities with a secondary aim of protecting or improving the lot of working children, not to legitimize what is prohibited by ILO standards' (ILO, 1993b, 3).

\subsection{Child Labour in the Globalised Economy}

While previously the ICFTU had supported and implemented the ILO's twoplank policy, as was noted above, from 1994 onwards it took a different direction. This had much to do with the collapse of the Soviet Union. The absence of the necessity to discuss the Cold War opened up the agenda for 'a real debate about improving the labour conditions for people around the world' (interview with a former ICFTU Staff member). In the new, globalised economy, child labour had become 'global child labour' (Nieuwenhuys, 2007) and the labour economists of the Western trade unions feared for their competitive position vis-à-vis cheap and child labour in other parts of the world. For them it was time to go back to the agenda of trade liberalisation from before WwI.

At this time, due to only few ratifications of Convention No. 138 and critical country reports, discussions were ongoing in the Office of the ILO about gradually replacing the objective of abolishing all child labour with the abolition of harmful work and thereby 'operationally re-defining child labour as work 
harmful to children' (interview with a former ILO Staff member). There was furthermore an informal consensus about leaving 'child labour' out of what became the Declaration on Fundamental Principles and Rights at Work. When the ICFTU was confronted with these developments, it fiercely objected and launched its own anti-child labour campaign pushing for more ratifications of Convention No. 138. According to one of the people behind the campaign, it was impossible to regulate and humanise child labour because the very nature of child labour is an exploitative relation in the marginal areas of the labour market, and thus a strategy of improving that relation will never work (interview with a former ICFTU Staff member). The ICFTU thus kept pushing the first plank, that is to say, the long-term objective of abolishing child labour, but replaced the second plank, that is to say, the short-term objective of improving the conditions of working children, with the promotion of Convention No. 138 and international instruments against the trade in goods produced by children (ICFTU, 1994). The ICFTU campaign played an important role in the development of the ILO's new convention on child labour and in its shifting policy.

\subsection{A New Convention on the Worst Forms of Child Labour}

The hard work undertaken by the ILO to put the spotlight on the problem of child labour, combined with advocacy efforts concerning the ratification and implementation of the 1989 UN Convention on the Rights of the Child (CRC) ${ }^{6}$ and the remarkable rise of international advocacy campaigns on violence against children (Poretti et al., 2014), pushed the issue of child labour higher up the international development agenda during the 1990s. There was a surge in coverage in both the academic literature and the mainstream media, and many other international Organizations started working on the topic as well. This also meant that more and more attention was drawn to the tension between the two planks of ILO policy and to the progressive and pragmatic approach adopted by the IPEC.

Now that the eyes of the world were on the programme, from within the IPEC office demands arose for a new or revised instrument that would be more in tune with reality (ILO, 2000). An unpublished internal review of the IPEC stressed the importance of a two-way translation of international child labour norms, in the sense that not only should it be the case that 'technical cooperation promotes the ratification and implementation of standards', but also that the ILO's practical activities should 'inspire our standard setting work and

6 United Nations Convention on the Rights of the Child, http://www.ohchr.org/EN/ProfessionalInterest/Pages/CRC.aspx (accessed on 1 June 2018). 
policy development' (ILO, 2000, 13). The IPEC's action programmes thus far had been aimed mainly at helping children who worked in the 'most intolerable', 'most hazardous' or 'worst' forms of child labour. For example, many of the IPEC programmes were dealing with child prostitution, something that Convention No. 138 had not foreseen. For the proponents of a new or revised Convention it was thus evident that it would be focused on these forms of child labour.

Besides the experiences gained from the IPEC projects in third world countries, a 1994 report of the Committee of Experts on the Application of Conventions and Recommendations provided important input on what was understood by the 'most intolerable' or 'worst' forms. Commenting on the application of the 1930 Forced Labour Convention (No. 29), 7 the Committee raised concern about 'forced child labour, and particularly the exploitation of children for prostitution and pornography. [...] No longer is such exploitation of children a responsibility only of the country in which it occurs, it is an international responsibility' (ILO, 1994, 28). The idea that the ILO would take up this international responsibility by means of a new convention provoked strong resistance from the technical and standards departments of the ILO's Office (ILO, 2000). Yet, all three constituencies of the ILo's tripartite system were in favour and in March 1996 the Governing Body accepted a proposal to place the adoption of a new convention on the agenda of the 1998 International Labour Conference. The cause was further strengthened with the adoption of a new resolution on child labour in 1996. The Resolution recalls the 1979 Resolution concerning the IYC and stresses that in the context of the progressive elimination of child labour there is the need to 'immediately proceed with the abolition of its most intolerable aspects' (ILO, 1996b). A few months later the ILO prepared a special report for the World Congress on Commercial Sexual Exploitation of Children, in Stockholm, in which it identifies prostitution and other forms of commercial sexual exploitation of children as a form of forced child labour. In a more elaborate publication on the reasons for a new convention, entitled 'Targeting the Intolerable', the ILO made clear its intentions for its new child labour policy. Instead of taking immediate action to improve the conditions of working children by regulating and humanising child labour, member states were now urged to give 'priority in the first instance to abolishing the worst and intolerable forms of child labour such as slavery and slave-like practices,

7 Convention concerning Forced or Compulsory Labour, http://www.ilo.org/dyn/normlex/en/ $\mathrm{f}$ ?p=1000:12100:0::NO::P12100_ILO_CODE:Co29 (accessed on 1 June 2018). In 2014 a protocol to the Convention was adopted, http://www.ilo.org/dyn/normlex/en/f?p=NORMLEXPUB:12100 :o::NO::P1210o_ILO_CODE:Po29 https://www.ilo.org/dyn/normlex/en/f?p=NORMLEXPUB:12 100:0::NO::P12100_ILO_CODE:Po29 (accessed on 1 June 2018). 
all forms of forced labour including debt bondage and child prostitution, and child work in hazardous occupations and industries' (ILO, 1996a, 115). This more narrow focus on the worst forms of child labour in the developing world quickly gained support from some of the larger industrialised countries, such as the US, Canada and Australia, who at that point in time were not willing to ratify Convention No. 138, which was considered difficult to ratify for federal states (interview with a former ICFTU Staff member).

During the negotiations over the content of the new convention the ICFTU drove a hard bargain on behalf of the trade unions. They had learned that there would be no 'social clause' in the new World Trade Organization (WTO) to enforce ILO labour standards and were adamant about reinforcing the ILO's original commitment to the abolition of all child labour, afraid of a so-called race to the bottom (Nieuwenhuys, 2007). The proposed formulation-'most intolerable forms of child labour' - was the subject of objections from the unions because this implied there were tolerable forms of child labour. They also demanded that despite the focus on the worst forms, the new Convention would explicitly refer to Convention No. 138 as the fundamental instrument and to the objective of the effective elimination of all forms of child labour. It was furthermore decided that both Convention No. 138 and the new Convention No. 182 would be amongst the so-called 'ILO fundamental Conventions' reflected in the Declaration on the Fundamental Principles and Rights at Work, which would mean that each individual member state would have to abide by them even if it had not specifically ratified them. The final version of the 1999 Convention No. 182 indeed refers to Convention No. 138 and to the 1996 Resolution, but no longer to the 1979 Resolution concerning the IYC. ${ }^{8}$ It was the writing on the wall for the 'old' two planks of ILO child labour policy.

After the adoption of Convention No. 182, which quickly became one of the most ratified of ILO conventions, the short-term objective of humanising child labour by regulating and improving working conditions gradually disappeared from the ILO's discourse. In practice, the two-plank policy seemed to remain an important part of the IPEC action programmes for at least a few more years. The IPEC Implementations Reports until 2001 provide statistics on the number of children impacted by programmes aimed at improving working conditions. In 2002 the ILO participated in the UN Special Session on Children. With regard to its role in drafting the outcome document of the Special Session, the ILO stated that 'discussions on how to incorporate the elimination of child

8 Convention concerning the Prohibition and Immediate Action for the Elimination of the Worst Forms of Child Labour, http://www.ilo.org/dyn/normlex/en/f?p=NORMLEXPUB:12100 :0::NO::P1210o_ILO_CODE:C182 (accessed on 1 June 2018). 
labour were continually side-tracked by proposals appealing for improvement of children's working conditions' (ILO, 2003, 16). Instead of referring to its longstanding two-plank policy, the ILO pointed out that Conventions No. 138 and No. 182 allow 'governments a certain degree of discretion and flexibility in setting the minimum age for admission to work' (ILO, 2003, 17). This proved to be an important turning point in the ILO's approach to child labour. From 2003 on, the IPEC Implementation Reports and other global policy publications on child labour (ILO, 2010, 2013, 2015; 2017) no longer mention the humanisation, regulation or improvement of the working conditions of children under the minimum age as a transitional policy measure. Instead the focus now lies on the 'sustained' eradication of all forms of child labour by 2025, as stipulated in Target 8.7 of the Sustainable Development Goals. The decade following the official introduction of the two-plank approach in 1979, which was previously described as a period that saw a surge in creative, pragmatic and progressive projects around the world (ILO, 1989), is now considered by the ILO as a period that 'represented a lost opportunity to launch a sustained worldwide campaign against child labour' (ILO, 2007, 10).

\section{$5 \quad$ Tense Translations of International Child Labour Norms}

The study of the shifts over a period of almost 100 years in ILO child labour policies shows that the international standards and norms on child labourwhich have both provided a basis for these policies, which in turn have influenced the development of the said standards and norms - are open to different interpretations. What is at work here are 'translations' of children's rights (Hanson and Nieuwenhuys, 2013), a concept that suggests that international discourse and policy making are not merely about transferring one idea or standpoint into another context but imply an active stance of reproducing and change (Freeman, 2009). As a theoretical construct, the concept of translation is a prompt to reflexivity and can make the active reproduction of meaning more explicit and open to debate. Considering the changes in the way that the ILO has addressed child labour over time, the translation concept reveals a series of tensions that deal with the regulation paradox, principled approaches versus pragmatism, and the place of the ILO within wider transnational developments.

A first tension that underlies many of the policy debates on children's work is about trying to advance apparently conflicting objectives. Can an activity that ultimately needs to be abolished at the same time be regulated? The ILO itself (1993b, see above) pointed at the risk that by regulating child labour, the 
target of eliminating child labour would by the same token be further removed instead of brought closer. Reversely, as was noted in a 1983 report by the ILO's Director General, there is a risk that legislation aiming at merely abolishing child labour, if it is not accompanied by socio-economic changes, 'may lead to greater clandestine work and more exploitative work situations' (ILO, 1983, 19). The ILO's long-held but now disappeared two-plank policy to regulate/humanise child labour in the short term while aiming at its abolition in the long term indeed reveals a 'regulation paradox', with which many other significant social debates also have to deal. Think, for instance, of the criminalisation versus regulation positions in debates about drug policy (Pardo, 2014) or the, in feminist circles, heated debate as to whether sex work should be regulated (granting specific rights to sex workers) or once and for all be outlawed by criminalising the customers (Munro and Della Giusta, 2016). Situations such as these, which express contradictory policy objectives, do not necessarily preclude the establishment of specific programmes that go in varied and even opposite directions. In the case of child labour policy, there seems to be no readily available way out of the regulation paradox, especially given the strong, principled positions that cut across the debates.

This leads to our second point, which deals with principled versus pragmatic approaches. Child labour policy is intimately connected to labour rights, human rights and children's rights, all fields that are traversed by firm principles, leading to deep-seated ideological positions. However, when making policy even in a field where strong moral convictions abound, at least some portions of pragmatism tend to crop up. When in 1919 the drafters of the ILO Constitution, at the last minute, decided to simply refer to 'the abolition of child labour' instead of a fixed minimum age, they did so for pragmatic reasons. It would be up to the constituents to decide on the exact standards in conventions, and up to member states to ratify them or not. When in 1946 the ILO decided to scrap from the Constitution the commitment to the abolition of child labour, it did so because of a lesson it had learned from the first 25 years - namely, that 'rigidity is likely to result in frustration rather than progress' (ILO, 1946, 15). When the ILO introduced in 1979 its two-plank policy, it did so because it faced the fact that for millions of children working in third world countries their work was inevitable. The standard-setting practice of the ILO was failing them, and member states were encouraged to progressively restrict, regulate and humanise child labour while striving for a socio-economic climate in which the abolition of child labour would be a realistic goal. Subsequently, when the IPEC was established in 1992, the ILO initially pursued its two-plank policy through technical assistance programmes on the ground. The success of the programme within as well as outside the 
ILO, and the concomitant rise of a worldwide campaign against child labour, provoked a shift of the ILO's child labour policy in a new direction. Ironically, the attempts to translate the ILO's progressive and practical activities from the field up into new standards rehabilitated a principled approach to the abolition of child labour. The extant pragmatic approach came to be replaced by a new form of pragmatism contained in the rigid 1999 Convention-pending the abolition of all forms of child labour, eliminating the worst forms firstleaving little room for flexible measures like the regulation and humanisation of child labour. One of our respondents, a former IPEC Staff member, provides a compelling explanation for the reappearance of entrenched ideologies in child labour policy, which he links with the return of trade unions to the now much more publicly exposed discussions. According to our respondent, trade unions are 'culturised in abolishing child labour', and so the question was not so much about data and the demonstrable realities of children in work, but rather 'about organised labour's sense of identity. They felt the integrity of the labour movement was at stake'.

Even if the institutionalised labour movement, employers' Organizations and governments, who make up the tripartite ILO constituency, are significant actors in the pursuit of social justice, decent work for all and the advancement of human and labour rights, they are not the only transnational actors in these fields. When developing policies and programmes related to child labour and children's work, the ILO must find its place amongst a myriad of other stakeholders including entities engaged with economic development such as the World Bank or the United Nations Development Programme (UNDP), children's rights agencies and bodies such as the United Nations International Children's Emergency Fund (UNICEF) or the Committee on the Rights of the Child, as well as civil society Organizations such as Save the Children or Human Rights Watch. Hence, the ILO as a transnational actor also needs to deal with the tension between its position as leader with regard to legal and technical questions in the field of child labour and the intimate connection of this field with larger developments related to human rights and global economic developments that lie beyond the control of any single actor. The ILo has, for instance, played a leading role in the drafting process of Article $3^{2}$ of the $\mathrm{CRC}$, which deals with children's economic exploitation; it has also largely influenced the positions of the Committee on the Rights of the Child and other children's rights entities including UNICEF and children's rights NGOs on how to interpret children's rights in relation to child labour (Hanson et al., 2015). More recently, through providing seed funding to facilitate its inception and serving as its secretariat during the initial stage, the ILO has played a central role in Alliance 8.7, a global partnership established within the framework of 
the 2030 Agenda for Sustainable Development that is committed to securing the prohibition and elimination of the worst forms of child labour and ending child labour in all its forms by 2025 .

The shift of the ILO's child labour policy from a position that included reasonable regulation to an almost exclusive abolitionist one was accompanied by an increase of referencing the most egregious forms of child exploitation such as child trafficking, the recruitment of child soldiers and slave-like practices. This is in line with a broader trend towards a moralisation of international human rights and children's rights discourses and policy (Poretti et al., 2014; see also Mouffe, 2005). The ILO has been only one of many transnational actors that emphasise dramatic stories, children's victimhood and vulnerability, leaving less space for addressing the political responsibility for dealing with economic and structural inequalities.

In our analysis of the history of the ILO's child labour policies, we have seen that, over the years, important changes have taken place in the way in which ideas and practices concerning child labour have been translated into international standards, discourses and policies. Working children's opinions and representations have played an indirect role, in particular during the period when the ILO designed and implemented its two-plank policy combining the long-term abolition with the short-term regulation of child labour. During its early years, the IPEC did foresee space, both in its discourse and in its programmes, for including working children's representations by explicitly including the regulation of children's work as part of its child labour policy and by giving financial support to working children's organisations. The remarkable policy shift operated at the end of the twentieth century has, however, seriously diminished these influences. Today, the abolitionist perspective upheld by trade unions, which are firmly established as one of the Organization's three constituencies, are at the core of the ILo's child labour discourse and policy. It is this particular language that is now dominating not only actual translation processes but also particular interpretations of the history of the ILO's child labour policy itself. Other particular languages that deal with regulating and humanising children's work, as a matter of principle or while awaiting total abolition, and that have been present for a long time in the ILO's history of child labour policy have slowly but surely disappeared from its discourse and practice. However, after 100 years of ILO child labour policies the Organization's own global estimates (ILO, 2017) show us that more than 150 million 
children are still working under the minimum age or in hazardous conditions. Just like in 1979 the ILO must face the fact that in many countries the social and economic conditions make the work of these children inevitable and that the short-term goal of improving their working conditions is just as relevant as it was back then. To shift its position at this time, the ILO would need to engage with the ever-growing body of literature providing evidence about the detrimental and beneficial consequences of work for children's well-being as well as about the impact of its own policy on children's lives (e.g. Morrow and Boyden, 2018; Bourdillon et al., 2010). In doing so, the ILO should actively collaborate with the research community, international development actors as well as local governments and social movements to develop locally relevant evidence-based policies for dealing with the diversity of children's work in the world's fast changing formal and informal economies.

\section{Acknowledgements}

Research for this article was conducted within the framework of the research project 'Living Rights in Translation: An interdisciplinary approach of working children's rights' funded by the Specialized Committee Interdisciplinary Research of the Swiss National Science Foundation (Project no. cri11__156831).

\section{References}

Black, M. (1986) The Children and the Nations (Layton: Peregrine Smith Books).

Bourdillon, M., D. Levison, W. Myers and B. White (2010) Rights and Wrongs of Children's Work (New Brunswick: Rutgers University Press).

Dahlén, M. (2007) The Negotiable Child. The ILO Child Labour Campaign 1919-1973 (Uppsala: Uppsala University).

Freeman, R. (2009) 'What is “translation"?', Evidence and Policy, 5(4), pp. 429-447, DOI: 10.1332/174426409X 478770 .

Hanson, K. and O. Nieuwenhuys (2013) 'Living rights, social justice, translations', in Hanson, K. and O. Nieuwenhuys (eds.) Reconceptualizing Children's Rights in International Development. Living Rights, Social Justice, Translations (Cambridge: Cambridge University Press), pp. 3-25.

Hanson, K. and A. Vandaele (2003) 'Working children and international labour law: A critical analysis', International Journal of Children's Rights, 11(1), pp. 73-146.

Hanson, K., D. Volonakis and M. Al-Rozzi (2015) 'Child labour, working children and children's rights', in W. Vandenhole, E. Desmet, D. Reynaert and S. Lembrechts (eds.) 
Routlegde International Handbook of Children's Rights Studies (London: Routlegde), pp. 316-33o.

ICFTU (International Confederation of Free Trade Unions) (1994) Stop Child Labour: ICFTU International Trade Union Campaign against Child Labour (Brussels: ICFTU).

ICFTU (1986) Breaking Down the Wall of Silence: How to Combat Child Labour (Brussels: ICFTU).

ILO (International Labour Organization) (2017) Global Estimates of Child Labour: Results and trends, 2012-2016 (Geneva: ILO), http://www.ilo.org/global/publications/ books/WCMS_575499/lang--en/index.htm (accessed on 1 June 2018).

ILO (2015) World Report on Child Labour 2015: Paving the way to decent work for young people (Geneva: ILO), http://www.ilo.org/ipec/Informationresources/ WCMS_358969/lang--en/index.htm (accessed on 1 June 2018).

ILO (2013) Marking progress against child labour-Global estimates and trends 200o2012 (Geneva: ILO), http://www.ilo.org/ipec/Informationresources/WCMS_221513/ lang--en/index.htm (accessed on 1 June 2018).

ILO (2010) Accelerating action against child labour-ILO Global report on child labour 2010 (Geneva: ILO), http://www.ilo.org/ipec/Informationresources/WCMS_IPEC _PUB_13853/lang--en/index.htm (accessed on 1 June 2018).

ILO (2007) The worldwide movement against child labour-Progress and future directions (Geneva: ILO), http://www.ilo.org/ipecinfo/product/download.do?type= document\&id=5168 (accessed on 1 June 2018).

ILO (2003) IPEC Action Against Child Labour 2002-2003: Progress and Future Priorities (Geneva: ILO), http://www.ilo.org/ipecinfo/product/viewProduct.do?productId $=163$ (accessed on 1 June 2018).

ILO (2000) IPEC: A Model of Technical Cooperation (document on file with authors).

ILO (1996a) Child Labour: Targeting the Intolerable (Geneva: ILO), http://www.ilo.org/ global/publications/ilo-bookstore/order-online/books/WCMS_PUBL_9221103285 _EN/lang--en/index.htm (accessed on 1 June 2018).

ILO (1996b) Resolution Concerning the Elimination of Child Labour, http://www.ilo.org/ public//english/standards/ipec/publ/law/ilc/ilc84/ilc84_1/index.htm (accessed on 12 June 2018).

ILO (1994) Report of the Committee of Experts on the Application of Conventions and Recommendations (Geneva: ILO).

ILO (1993a) IPEC Implementation Report 1992-1993 (Geneva: ILO).

ILO (1993b) Towards the Abolition of Child Labour: ILO Policy and its Implications for ILO Technical Cooperation Activities (Geneva: ILO).

ILO (1989) Still so Far to Go: Child Labour in the World Today. Special report on the occasion of the Tenth Anniversary of the International Year of the Child (Geneva: ILO).

ILO (1985) Towards a Global Programme of Action on Child Labour (Geneva: ILO). 
ILO (1983) Child Labour. Extract from the Report of the Director-General to the International Labour Conference, 6gth Session, 1983 (Geneva: ILO).

ILO (1979a) Children at Work (Geneva: ILO).

ILO (1979b) Declaration by the Director-General of the ILO Concerning the International Year of the Child (Geneva: ILO).

ILO (1979c) Resolution Concerning the International Year of the Child and the Progressive Elimination of Child Labour and Transitional Measures (Geneva: ILO).

ILO (1978a) Children and Work. An ILO Policy Framework for the IYC 1979 (Geneva: ILO).

ILO (1978b) International Year of The Child (IYC). Synthesis of ILO Inputs (March 1977March 1978) (Geneva: ILO).

ILO (1946) International Labour Conference Twenty-Ninth Session Montreal, 1946. Constitutional Questions Part 1: Reports of the Conference Delegation on Constitutional Questions (Montreal: ILO).

ILO (1945a) International Labour Conference. Twenty-Seventh Session Paris, 1945. Protection of Children and Young Workers (First Discussion) (Geneva: ILO).

ILO (1945b) Resolution Concerning the Protection of Children and Young Workers (Geneva: ILO).

ILO (1919) Constitution of the ILO (Part XIII of the Versailles Peace Treaty), http://www .ilo.org/public/libdoc/historical/1901-200o/53372.pdf (accessed on 12 June 2018).

Maupain, F. (2013) The Future of the International Labour Organization in the Global Economy (London: Bloomsbury Publishing).

Morrow, G. and J. Boyden (2018) Responding to Children's Work: Evidence from the Young Lives study in Ethiopia, India, Peru and Vietnam (Oxford: Young Lives).

Mouffe, C. (2005) On the Political. Thinking in Action (London: Routledge).

Munro, V.E. and M. Della Giusta (2016) Demanding Sex: Critical Reflections on the Regulation of Prostitution (London: Routledge).

Nieuwenhuys, O. (2007) 'Embedding the global womb: Global child labour and the new policy agenda', Children's Geographies, 5(1-2), pp. 149-163, DOI: https://doi .org/10.1080/14733280601108312.

Pardo, B. (2014) 'Cannabis policy reforms in the Americas: a comparative analysis of Colorado, Washington, and Uruguay', International Journal of Drug Policy, 25(4), pp. 727-735, DOI: 10.1016/j.drugpo.2014.05.010.

Poretti, M., K. Hanson, F. Darbellay and A. Berchtold (2014) 'The rise and fall of icons of "stolen childhood" since the adoption of the UN Convention on the Rights of the Child', Childhood, 21(1), pp. 22-38, DOI: https://doi.org/10.1177/0907568213481816. 